At-Turats

Jurnal Pemikiran Pendidikan Islam

journal homepage: http://jurnaliainpontianak.or.id/index.php/atturats

\title{
Peran Profesionalisme Guru Pendidikan Agama Islam dalam Peningkatan Mutu Sekolah (Studi di SMK Bhakti Anindya, SMKN 8 dan SMK Tiara Aksara Kota Tangerang Banten)
}

\author{
Anis Fauzi \\ Dosen Jurusan PGRA \\ Institut Agama Islam Negeri Sultan Maulana Hasanuddin Banten \\ jantera_anis@yahoo.com
}

Siti Sulastri

SMK Negeri 8 Kota Tangerang Banten

sitisulastri81076@gmail.com

\begin{abstract}
A B S T R A K
The primary issue in this study is how the level of professionalism of teachers of Islamic education in improving the quality of school at SMK (vocational high school) Bhakti Anindya, SMKN 8, and SMK Tiara Angkasa of Tangerang is. This study aims to find the level of professionalism of teachers of Islamic education of SMK Bhakti Anindya, SMKN 8, and SMK Tiara Angkasa of Tangerang in overcoming barriers to school's quality. The purpose of this study is to know the importance of Islamic Education Teacher's Professionalism in improving the quality of learning. This study employs a combination of design/model of sequential exploratory, with its main steps: In the first stage, the study conducts a qualitative method to determine the setting of study that has problem. In the second stage, this study employs quantitative methods to test the hypothesis obtained in the first stage. The population of this study is 150 students with a $5 \%$ error, so the number of the sample is 105 students. The sampling collection is conducted by using proportional random sampling. The instrument of this study is collected through questionnaires that are arranged according to the Likert scale model. The results reveal that there are positive contributions from the Professionalism of Teacher of Islamic Education to the quality of the school. This is shown by the determination coefficient of $44.89 \%$, which provide simple information that $44.89 \%$ of school quality is determined by the Islamic Education Teacher's Professionalism. Thus it can be concluded that the higher the professionalism of teachers of Islamic education, the higher the quality of schools.
\end{abstract}

Key Words: Profesionalism, Quality of School, Islamic Education Teacher

\section{PENDAHULUAN}

Sumber daya manusia yang berkualitas sangat dibutuhkan di era global ini. Sumber daya manusia tersebut harus memiliki kompetensi tertentu agar bisa beradaptasi dengan kondisi yang ada di lapangan. Kompetensi yang dimiliki bisa dibidang komunikasi, teknologi, pertanian dan lain-lain.
Untuk memenuhi kebutuhan akan sumber daya manusia di atas, pemerintah mulai membuka sekolah menengah kejuruan (SMK) di berbagai bidang. Kearah depan ternyata SMK tumbuh dengan pesat, karena banyak kesempatan menanti di dunia kerja.

Banyak kalangan menilai bahwa mutu pendidikan di Indonesia masih jauh dari 
yang diharapkan, apalagi jika dibandingkan dengan mutu pendidikan di negara lain. Hasil survey United Nation Development Program atau UNDP) yang dilakukan pada tahun 2005 tentang mutu pendidikan di kawasan Asia, menempatkan Indonesia di rangking 10 dari 14 negara ${ }^{1}$.

Rendahnya sumber daya manusia Indonesia berdasarkan hasil survey United Nation Development Program atau (UNDP) tersebut akibat rendahnya mutu pendidikan di berbagai jenis dan jenjang pendidikan, karena itu salah satu kebijakan pokok pembangunan pendidikan nasional ialah peningkatan mutu dan relevansi pendidikan ${ }^{2}$. Selain itu, perluasan dan pemerataan pendidikan serta akuntabilitas juga menjadi kebijakan pembangunan pendidikan nasional (UUSPN No. 20 Tahun 2003).

Salah satu faktor penyebab rendahnya mutu pendidikan di Indonesia adalah karena lemahnya para guru dalam menggali potensi anak didik. Para pendidik seringkali memaksakan kehendaknya tanpa pernah memperhatikan kebutuhan, minat dan bakat yang dimiliki siswanya. Kelemahan para pendidik kita, mereka tidak pernah menggali masalah dan potensi para siswa. Pendidikan seharusnya memperhatikan kebutuhan siswa bukan malah memaksakan sesuatu yang membuat anak kurang nyaman dalam menuntut ilmu. Proses pendidikan yang baik adalah dengan memberikan kesempatan pada anak didik untuk kreatif. Hal itu harus dilakukan, sebab pada dasarnya gaya berfikir anak tidak bisa diarahkan.

Selain kurang kreatifnya para pen-

1 Irfan Jaya, "Permasalahan Pendidikan di Indonesia”, http:/vancebatosai.blogspot.com, diakses 24 Oktober 2011

2 Abdul Hadis dan Nurhayati, Manajemen Mutu Pendidikan, Bandung: Alfabeta, 2012: 2 didik dalam membimbing siswa, kurikulum yang sentralistik membuat potret pendididikan semakin buram. Kurikulum hanya didasarkan pada pengetahuan pemerintah tanpa memperhatikan kebutuhan masyarakat. Lebih parah lagi, pendidikan tidak mampu menghasilkan lulusan yang kreatif. Jadi para lulusan hanya pintar mencari kerja dan tidak bisa menciptakan lapangan kerja sendiri, padahal lapangan pekerjaan yang tersedia terbatas. Kualitas Indonesia sangat memprihatinkan, berdasarkan analisa dari badan dunia (UNESCO), kualitas guru Indonesia menempati peringkat terakhir dari 14 negara berkembang di Asia pasifik. ${ }^{3}$

Dalam perspektif makro banyak faktor yang mempengaruhi mutu pendidikan, diantaranya faktor kurikulum, kebijakan pendidikan, fasilitas pendidikan, aplikasi teknologi informatika dan komunikasi dalam pendidikan, pendekatan pendidikan yang tepat, biaya pendidikan yang memadai, manajemen pendidikan yang profesional, metode evaluasi pendidikan yang tepat, serta sumber daya manusia para pelaku pendidikan yang terlatih, berpengetahuan, berpengalaman, dan profesional. $^{4}$

Faktor yang tidak kalah penting yaitu adanya standar nasional pendidikan yang menjadi norma acuan dalam penyelenggaraan pendidikan nasional yang mencakup standar: isi, proses, kompetensi lulusan, standar pendidik dan tenaga kependidikan, standar sarana dan prasana, standar pengelolaan, pembiayaan dan standar penilaian pendidikan ${ }^{5}$.

\footnotetext{
3 Wawan Jakwan, "Pendidikan dan pengajaran", http://www.fisika79.wordpress.com, diakses 16 Januari 2014

${ }^{4}$ Abdul Hadis dan Nurhayati, Op-cit hal 3

${ }^{5}$ http://www.scribd.com/doc/183861226/ Peraturan-Pemerintah-Nomor-19-Tahun-2005tentang-Standar-Nasional-Pendidikan-Lengkap, diakses 13 November 2013
} 
Dalam perspektif mikro atau tinjauan secara sempit dan khusus, faktor dominan yang berpengaruh dan berkontribusi besar terhadap mutu pendidikan ialah guru yang profesional dan guru yang sejahtera. Oleh karena itu, guru sebagai suatu profesi harus profesional dalam melaksanakan berbagai tugas pendidikan dan pengajaran, pembimbingan dan pelatihan yang diamanahkan kepadanya $^{6}$.

Menurut Usman (2014:12), ada tiga faktor yang menjadi penyebab rendahnya mutu pendidikan di negara kita, yaitu: Faktor pertama, kebijakan dan penyelenggaraan pendidikan nasional menggunakan pendekatan education production atau input-input analisis yang tidak dilaksanakan secara konsekuen; Faktor kedua, yaitu penyelenggaraan pendidikan nasional dilakukan secara sentralistik, sehingga menempatkan sekolah sebagai penyelenggara pendidikan sangat tergantung pada keputusan birokrasi; Sedangkan faktor ketiga, yaitu peran serta masyarakat, khususnya orangtua siswa dalam penyelenggaraan pendidikan selama ini sangat minim? ${ }^{7}$.

Guru yang bermutu adalah mereka yang mampu membelajarkan murid secara efektif sesuai dengan kendala, sumber daya dan lingkungannya. Di lain pihak, upaya menghasilkan guru yang bermutu juga merupakan tugas yang tidak mudah. Mutu guru juga berarti tenaga pengajar yang mampu melahirkan lulusan yang bermutu, sesuai dengan kebutuhan penyelenggaraan berbagai jalur, jenis dan jenjang pendidikan. Di lain pihak, mutu guru sangat berkaitan dengan pengakuan masyarakat akan status guru se-

\footnotetext{
${ }^{6}$ Abdul Hadis dan Nurhayati, Loc.cit hal 4

7 Usman Husaini, Manajemen: teori,praktik $\&$ riset pedidikan, (Jakarta: Bumi Aksara, 2014), hal 12
}

bagai jabatan profesional ${ }^{8}$.

Sehubungan dengan kualitas tenaga kerja diperlukan demi kelangsungan suatu organisasi dan khususnya pada SMK Bhakti Anindya, SMKN 8 dan SMK Tiara Aksara yang terus melakukan upaya untuk meningkatkan mutu sekolahnya, maka salah satu upaya pokok yang dilakukannya kini adalah meningkatkan kinerja guru melalui keprofesionalan guru yang dapat memberikan peningkatan mutu di SMK Bhakti Anindya, SMKN 8 dan SMK Tiara Aksara dalam memperoleh lulusan yang berkualitas.

Permasalahan pokok dalam penelitian ini adalah bagaimana tingkat Profesionalisme Guru Pendidikan Agama Islam dalam meningkatkan mutu sekolah di SMK Bhakti Anindya, SMKN 8 dan SMK Tiara Aksara Kota Tangerang; dan bagaimana pengaruh Profesionalisme Guru Pendidikan Agama Islam dalam meningkatkan mutu pendidikan di SMK Bhakti Anindya, SMKN 8 dan SMK Tiara Aksara Kota Tangerang Provinsi Banten?

Tujuan utama penelitian ini adalah mengetahui Profesionalisme Guru Pendidikan Agama Islam di SMK Bhakti Anindya, SMKN 8 dan SMK Tiara Aksara Kota Tangerang dalam mengatasi hambatan mutu sekolah. Adapun kegunaan penelitian ini dapat mengetahui secara jelas pentingnya Profesionalisme Guru Pendidikan Agama Islam dalam meningkatkan mutu pendidikan sekolah, terutama dalam memperbaiki kualitas pembelajaran dengan sebaik-baiknya.

\section{PEMBAHASAN}

\section{A. Karakteristik Guru PAI}

Karakteristik guru adalah segala

${ }^{8}$ Abin Syamsuddin Makmun, Psikologi Kependidikan, (Bandunr : PT Remaja Rosdakarya, 2012), hal 15 
tindak tanduk atau sikap dan perbuatan guru baik di sekolah maupun di lingkungan masyarakat. Misalnya, sikap guru dalam meningkatkan pelayanan, meningkatkan pengetahuan, memberi arahan, bimbingan dan motivasi kepada peserta didik, cara berpakaian, berbicara, dan berhubungan baik dengan peserta didik, teman sejawat, serta anggota masyarakat lainnya9 .

Seorang ahli pendidik Islam, AnNahlawi ${ }^{10}$ membagi karakteristik guru profesional muslim dalam beberapa bentuk berikut ini:

a. Mempunyai watak dan sifat rabbaniyah yang terwujud dalam tujuan, tingkah laku dan pola pikirnya.

b. Bersifat ikhlas, melaksanakan tugasnya semata-mata untuk mencari keridhaan Allah dan menegakkan kebenaran.

c. Bersifat sabar dalam mengajarkan berbagai pengetahuan kepada siswa

d. Jujur dalam menyampaikan apa yang diketahuinya.

e. Senantiasa membekali diri dengan ilmu.

f. Mampu menggunakan metode mengajar secara bervariasi.

g. Mampu mengelola kelas dan peserta didik, tegas dalam bertindak dan profesional.

h. Mengetahui kehidupan psikis peserta didik.

i. Tanggap terhadap berbagai kondisi dan perkembangan dunia yang dapat mempengaruhi jiwa, keyakinan atau pola berfikir peserta didik.

j. Berlaku adil terhadap peserta didiknya.

Guru dalam Islam adalah orang yang bertanggung jawab terhadap perkembangan

9 Yunus Abu bakar dan Syarifan Nurjan,

"Profesi Keguruan", (Surabaya : AprintA,2009), h 7.

${ }^{10}$ Arifuddin Arif, Pengantar Ilmu Pendidikan

Islam, (Jakarta: Kultura GP Press Group, 2008), hal 64. anak didiknya dengan mengupayakan seluruh potensinya, baik potensi afektif, potensi kognitif maupun potensi psikomotorik. Guru juga berarti orang dewasa yang bertanggung jawab memberikan pertolongan pada anak didik dalam perkembangan jasmani dan rohaninya agar mencapai tingkat kedewasaan serta mampu berdiri sendiri dalam memenuhi tugasnya sebagai hamba Allah dan dia mampu sebagai makhluk sosial dan makhluk individu yang mandiri ${ }^{11}$.

\section{B. Mutu Sekolah}

Menurut Juran, mutu adalah kecocokan penggunaan produk untuk memenuhi kebutuhan dan kepuasan pelanggan. Kecocokan pengguna produk didasari atas lima ciri yaitu teknologi (kekuatan), psikologis (citrarasa atau status), waktu (kehandalan), kontraktual (jaminan) dan etika (sopan santun) $)^{12}$.

Dalam kelembagaan sekolah, pengguna produk merupakan dunia industri, dimana siswa sebagai produk harus bisa menjadi tenaga ahli yang dibutuhkan dunia kerja. Pengguna produk atau perusahaan membutuhkan pekerja yang mengerti teknologi, pekerja yang handal, bisa kerja sesuai target, dapat diandalkan dan memiliki etika kerja.

Menurut Crosby (Abdul Hadis,2012:85), mutu adalah conformance to requirement, yaitu sesuai dengan yang disyaratkan atau distandarkan. Suatu produk memiliki mutu apabila sesuai dengan standar atau kriteria mutu yang telah ditentukan. Standar mutu tersebut meliputi bahan

\footnotetext{
${ }^{11}$ Muhammad Nurdin, 'Kiat Menjadi Guru Profesional”, (Yogyakarta : Prismasophie, 2004), hal. 156).

${ }^{12}$ Abdul Hadis , "Manajemen Mutu Pendidikan”, (Bandung:Alfabeta, 2012), hal 84
} 
baku, proses produksi dan produk jadi ${ }^{13}$.

Sekolah yang bermutu dinilai dari keadaan fisik bangunannya, suasana proses pembelajarannya dan output keluaran peserta didiknya. Apakah output sudah sesuai dengan selera dunia industry atausudah memiliki keahlian sesuai dengan yang dibutuhkan pencari kerja.

W. Edwards Deming (Abdul Hadis, 2012: 85), menyatakan bahwa mutu adalah kesesuaian dengan kebutuhan pasar atau konsumen. Dalam arti ini, mutu adalah apa saja yang menjadi kebutuhan dan keinginan konsumen. Kalau dilihat dari definisi di atas, keinginan konsumen yang selalu berubah-berubah akan mempengaruhi mutu suatu produk sesuai dengan yang dikehendaki konsumen ${ }^{14}$. Menurut Edwar Sallis (Umiarso dan Imam Gojali, 2011: 121), mutu dipandang sebagai sebuah konsep yang absolut sekaligus relatif. Dalam artian absolut, mutu sama halnya dengan sifat baik, cantik, dan benar, merupakan suatu idealisme yang tidak dapat dikompromikan. Sesuatu yang bermutu bagian dari standar yang sangat tinggi dan tidak dapat diungguli.Adapun mutu itu relatif dipandang sebagai sesuatu yang melekat pada sebuah produk yang sesuai dengan kebutuhan pelanggannya. Oleh karena itu, produk ataulayanandianggap bermutu bukankarena ia mahal dan eksklusif, tetapi karena memiliki nilai, misalnya keaslian produk, wajar, dan familiar ${ }^{15}$.

\section{Metode Penelitian}

Penelitian ini menggunakan metode kombinasi desain/model sequential ex-

\footnotetext{
${ }^{13}$ Ibid, hal 85

${ }^{14}$ Ibid, hal. 85

${ }^{15}$ Umiarso dan Imam Gojali, "Manajemen Mutu Sekolah di Era Otonomi Pendidikan, (Jogjakarta: IRCiSoD, 2011), hal. 121
}

ploratory. Sugiyono (2014:400) menyatakan bahwa: Pertama, kedua metode tersebut dapat digabungkan tetapi digunakan secara bergantian. Pada tahap pertama menggunakan metode kuantitatif, sehingga ditemukan hipotesis, selanjutnya hipotesis tersebut diuji dengan metode kualitatif;Kedua, metode penelitian tidak dapat digabungkan dalam waktu bersamaan, tetapi hanya teknik pengumpulan data yang dapat digabungkan ${ }^{16}$.

Langkah-langkah utama penelitian kombinasi desain/model sequential exploratory yaitu: pada tahap pertama, penelitian menggunakan metode kualitatif untuk menentukan seting penelitian tempat yang memiliki masalah. Selanjutnya peneliti melakukan kajian teori perspektif yang berfungsi untuk memandu peneliti dalam mengumpulkan data dan analisis data. Setelah itu peneliti masuk ke seting penelitian dengan melakukan pengumpulan data dan analisis data kualitatif, dan akhirnya peneliti dapat menemukan gambaran yang utuh dari obyek penelitian tersebut, mengkonstruksi makna dan hipotesis-hipotesis. Pada tahap kedua, peneliti menggunakan metode kuantitatif yang berfungsi untuk menguji hipotesis yang ditemukan pada penelitian tahap pertama.

Pengumpulan data dapat dilakukan dalam berbagai seting, berbagai sumber dan berbagai cara. Bila dilihat dari sumber datanya, maka pengumpulan data dapat menggunakan sumber primer dan sumber sekunder. Pada penelitian ini, sumber data primernya yaitu siswa, guru-guru, kepala sekolah dan ketua yayasan yang ada diketiga sekolah yaitu di SMK Bhakti

${ }^{16}$ Sugiyono, "Metode Penelitian Kombinasi (Mixed Methods)", ( Bandung : Alfabeta, 2014), h. 400 
Anindya, SMKN 8 dan SMK Tiara Aksara Kota Tangerang. Sedangkan sumber data sekunder di dapat dari masyarakat sekitar sekolah dan dokumen sekolah.

Bila dilihat dari teknik pengumpulan data, maka teknik pengumpulan data dilakukan dengan cara melakukan: observasi (pengamatan), interview (wawancara), kuesioner (angket), dokumentasi, dan catatan lapangan.

Penelitian ini menggunakan sampel siswa yang diambil dari populasi sebanyak 150 siswa dengan kesalahan 5\%, maka jumlah anggota sampelnya sebanak 105 siswa. Pengambilan sampel dilakukan dengan proportional random sampling.

Instrumen yang digunakan dalam penelitian ini adalah kuesioner (angket) yang disusun menurut model Skala Likert. Instrumen disusun dalam bentuk kalimat pernyataan yang berhubungan dengan ketiga variabel penelitian. Sedangkan bentuk butir-butir kuesioner yang disusun dalam pernyataan akan dijawab oleh responden. Instrumen ini antara lain untuk pengukuran variabel bebas $\left(\mathrm{X}_{1}\right)$ yaitu profesionalisme Guru Pendidikan Agama Islam dan variabel terikat (Y) yaitu mutu sekolah.

Pendeskripsian data menggunakan statistik deskriptif. Statistik deskriptif adalah statistik yang hanya berfungsi untuk mengorganisasi, menganalisa serta memberikan pengertian mengenai data (keadaan, gejala, persoalan) dalam bentuk angka agar dapat diberikan gambaran secara teratur, ringkas dan jelas ${ }^{17}$.

${ }^{17}$ Darwyan Syah dan Supardi, "Pengantar Statistik Pendidikan”, Jakarta : Diadit Media, 2009, hal $3 \mathrm{~N}$

\section{Hasil dan Pembahasan}

\section{Deskripsi Mutu Sekolah}

Rentangan skor jawaban responden pada variabel mutu sekolah dijaring berdasarkan hasil dari penyebaran angket terhadap 105 responden, untuk data mutu sekolah diperoleh skor antara 48 sampai dengan 79, skor rata-rata 62,533 modus 67,465 median 67,573 varians 293,002 dan standar deviasi 17,117. Skor rata-rata mutu sekolah sebesar 62,533 bila dibandingkan dengan skor ideal sebesar 80 tingkat ketercapaiannya $78 \%$ termasuk dalam kategori tinggi. Distribusi frekuensi variabel mutu sekolah dapat dilihat pada tabel 1:

Tabel 1

\section{Distribusi Frekuensi Mutu Sekolah}

\begin{tabular}{lccccc}
\hline $\begin{array}{l}\text { Inter- } \\
\text { val }\end{array}$ & $\begin{array}{c}\text { Fre- } \\
\text { kuensi }\end{array}$ & $\begin{array}{c}\text { Per- } \\
\text { sentase }\end{array}$ & $\begin{array}{c}\text { Titik } \\
\text { tengah }\end{array}$ & $\begin{array}{c}\text { Batas } \\
\text { nyata }\end{array}$ & Interpretasi \\
\hline $48-51$ & 5 & 5 & 49,5 & $47,5-51,5$ & $\begin{array}{c}\text { Sangat } \\
\text { rendah }\end{array}$ \\
\hline $52-55$ & 9 & 9 & 53,5 & $51,5-55,5$ & Rendah \\
\hline $56-59$ & 15 & 14 & 57,5 & $55,5-59,5$ & Kurang \\
\hline $60-63$ & 34 & 32 & 61,5 & $59,5-63,5$ & Cukup \\
\hline $64-67$ & 22 & 21 & 65,5 & $63,5-67,5$ & $\begin{array}{c}\text { Cukup } \\
\text { baik }\end{array}$ \\
\hline $68-71$ & 11 & 10 & 69,5 & $67,5-71,5$ & Baik \\
\hline $72-75$ & 5 & 5 & 73,5 & $71,5-75,5$ & $\begin{array}{c}\text { Sangat } \\
\text { baik }\end{array}$ \\
\hline $76-79$ & 4 & 4 & 77,5 & $75,5-79,5$ & Sempurna \\
\hline Jumlah & 105 & 100 & & & \\
\hline
\end{tabular}

Tabel diatas menunjukkan distribusi frekuensi kelas interval pertama yaitu antara $48-51$ frekuensi berjumlah 5 orang. Merupakan $5 \%$ dari jumlah responden, dengan kategori sangat rendah. Distribusi frekuensi kelas interval kedua yaitu antara $52-55$ frekuensi berjumlah 9 orang. Merupakan 9\% dari jumlah responden, dengan kategori rendah. Distribusi frekuensi kelas interval ketiga yaitu antara 56 - 59 frekuensi berjum- 
lah 15 orang. Merupakan 14\% dari jumlah responden, dengan kategori kurang.

Distribusi frekuensi kelas interval keempat yaitu antara 60- 63 frekuensi berjumlah 34 orang. Merupakan 32\% dari jumlah responden, dengan kategori cukup. Distribusi frekuensi kelas interval kelima yaitu antara 64-67 frekuensi berjumlah 22 orang. Merupakan $21 \%$ dari jumlah responden, dengan kategori cukup baik. Distribusi frekuensi kelas interval keenam yaitu antara $68-71$ frekuensi berjumlah 11 orang. Merupakan $10 \%$ dari jumlah responden, dengan kategori baik. Distribusi frekuensi kelas interval ketujuh yaitu antara $72-75$ frekuensi berjumlah 5 orang. Merupakan 5\% dari jumlah responden, dengan kategori sangat baik dan distribusi frekuensi kelas interval kedelapan yaitu antara $76-79$ frekuensi berjumlah 4 orang. Merupakan 4\% dari jumlah responden, dengan kategori sempurna.

\section{Gambar 1}

\section{Histogram Frekuensi Mutu Sekolah}

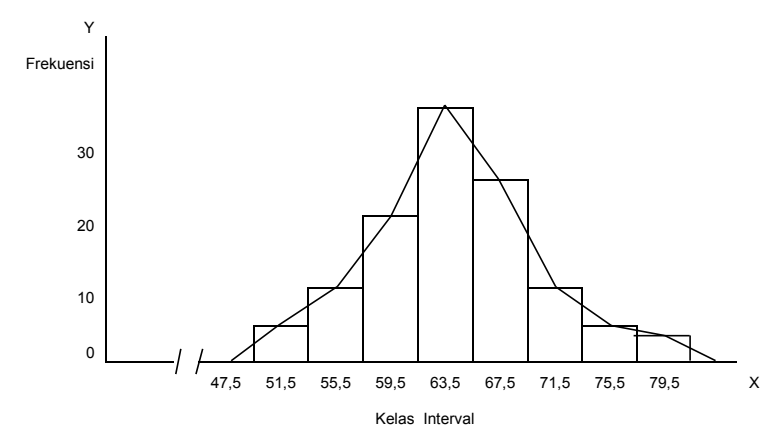

Gambar diatas menunjukkan histogram frekuensi pertama batas nyata antara 47,5-51,5 frekuensinya berjumlah 5 orang. Histogram frekuensi kedua batas nyata antara 51,5-55,5 frekuensinya berjumlah 9 orang. Histogram frekuensi ketiga batas nyata antara 55,5-59,5 frekuensinya berjumlah 15 orang.Histogram frekuen- si keempat batas nyata antara 59,5-63,5 frekuensinya berjumlah 34 orang. Histogram frekuensi kelima batas nyata antara 63,5-67,5 frekuensinya berjumlah 22 orang. Histogram frekuensi keenam batas nyata antara 67,571,5 frekuensinya berjumlah 11 orang. Histogram frekuensi ketujuh batas nyata antara 71,5-75,5 frekuensinya berjumlah 5 orang. Dan histogram frekuensi kedelapan batas nyata antara 75,5-79,5 frekuensinya berjumlah 4 orang.

\section{Deskripsi Profesionalisme Guru Pendidikan Agama Islam}

Rentangan skor jawaban responden pada variabel Profesionalisme Guru Pendidikan Agama Islam dijaring berdasarkan hasil dari penyebaran angket terhadap 105 responden. Data mutu sekolah diperoleh skor antara 48 sampai dengan 79 skor rata-rata 62,513 modus 67,465 median 67,573. Varians 293,002 dan standar deviasi 17,117 skor rata-rata mutu sekolah sebesar 62,419 Bila disbandingkan dengan skor ideal sebesar 80 tingkat ketercapaiannya 78\% termasuk dalam kategori baik.

Distribusi frekuensi variabel Profesionalisme Guru Pendidikan Agama Islam dapat dilihat pada tabel 2, sedangkan gambar histogram distribusi frekuensi dapat dilihat pada gambar 2 
Tabel 2

Distribusi Frekuensi Profesionalisme Guru Pendidikan Agama Islam

\begin{tabular}{cccccc}
\hline $\begin{array}{c}\text { Inter- } \\
\text { val }\end{array}$ & Fi & $\begin{array}{c}\text { Per- } \\
\text { sentasi }\end{array}$ & $\begin{array}{c}\text { Titik } \\
\text { tengah }\end{array}$ & $\begin{array}{c}\text { Batas } \\
\text { nyata }\end{array}$ & $\begin{array}{c}\text { Inter- } \\
\text { pretasi }\end{array}$ \\
\hline $48-51$ & 5 & 5 & 49,5 & $47,5-51,5$ & $\begin{array}{c}\text { Sangat } \\
\text { rendah }\end{array}$ \\
\hline $52-55$ & 9 & 9 & 53,5 & $51,5-55,5$ & Rendah \\
\hline $56-59$ & 17 & 16 & 57,5 & $55,5-59,5$ & Kurang \\
\hline $60-63$ & 32 & 30 & 61,5 & $59,5-63,5$ & Cukup \\
\hline $64-67$ & 23 & 22 & 65,5 & $63,5-67,5$ & $\begin{array}{c}\text { Cukup } \\
\text { baik }\end{array}$ \\
\hline $68-71$ & 11 & 10 & 69,5 & $67,5-71,5$ & Baik \\
\hline $72-75$ & 5 & 5 & 73,5 & $71,5-75,5$ & $\begin{array}{c}\text { Sangat } \\
\text { baik }\end{array}$ \\
\hline $76-79$ & 3 & 3 & 77,5 & $75,5-79,5$ & $\begin{array}{c}\text { Sem- } \\
\text { purna }\end{array}$ \\
\hline Jumlah & 105 & 100 & & & \\
\hline
\end{tabular}

Tabel diatas menunjukkan distribusi frekuensi kelas interval pertama yaitu antara 48-51 frekuensi berjumlah 5 orang, merupakan $5 \%$ dari jumlah responden, dengan kategori sangat rendah. Distribusi frekuensi kelas interval kedua yaitu antara 52 - 55 frekuensi berjumlah 9 orang, merupakan $9 \%$ dari jumlah responden, dengan kategori rendah. Distribusi frekuensi kelas interval ketiga yaitu antara 56-59 frekuensi berjumlah 17 orang, merupakan $16 \%$ dari jumlah responden, dengan kategori kurang.

Distribusi frekuensi kelas interval keempat yaitu antara 60-63 frekuensi berjumlah 32 orang, merupakan 30\% dari jumlah responden, dengan kategori cukup. Distribusi frekuensi kelas interval kelima yaitu antara $64-67$ frekuensi berjumlah 23 orang,merupakan $22 \%$ dari jumlah responden, dengan kategori cukup baik. Distribusi frekuensi kelas interval keenam yaitu antara 68-71 frekuensi berjumlah
11 orang,merupakan 10\% dari jumlah responden, dengan kategori baik. Distribusi frekuensi kelas interval ketujuh yaitu antara 72 - 75 frekuensi berjumlah 5 orang, merupakan 5\% dari jumlah responden, dengan kategori sangat baik; dan distribusi frekuensi kelas interval kedelapan yaitu antara $76-79$ frekuensi berjumlah 3 orang, merupakan 3\% dari jumlah responden, dengan kategori sempurna.

Gambar 2

Histogram Frekuensi Profesionalisme

Guru Pendidikan Agama Islam

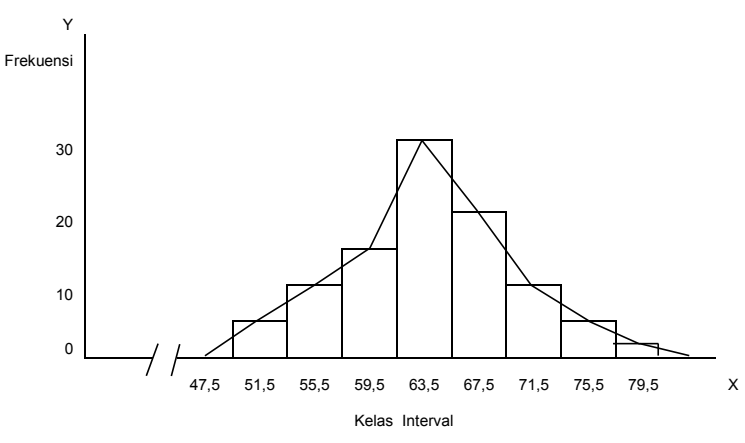

Gambar diatas menunjukkan histogram frekuensi pertama batas nyata antara 47,5-51,5 frekuensinya berjumlah 5 orang. Histogram frekuensi kedua batas nyata antara 51,5-55,5 frekuensinya berjumlah 9 orang. Histogram frekuensi ketiga batas nyata antara 55,5-59,5 frekuensinya berjumlah 16 orang. Histogram frekuensi keempat batas nyata antara 59,5-63,5 frekuensinya berjumlah 30 orang. Histogram frekuensi kelima batas nyata antara 63,5-67,5 frekuensinya berjumlah 22 orang. Histogram frekuensi keenam batas nyata antara 67,5-71,5 frekuensinya berjumlah 10 orang.Histogram frekuensi ketujuh batas nyata antara 71,575,5 frekuensinya berjumlah 5 orang.Dan histogram frekuensi kedelapan batas nyata antara 75,5-79,5 frekuensinya berjumlah 3 orang. 


\section{Pengujian Hipotesis}

Hasil perhitungan uji t korelasi diperoleh angka sebesar 9,17. Jika dikonsultasikan dengan $\mathrm{t}_{\text {tabel }}$ dengan taraf signifikan 0,05 diperoleh angka $t_{\text {tabel }}$ sebesar 1,67 . Hal ini menunjukkan adanya hubungan yang positif antara variabel $\mathrm{X}$ (Profesionalisme Guru Pendidikan Agama Islam) dengan variabel Y (Mutu Sekolah), karena $t_{\text {hitung }}$ lebih besar dari $t_{\text {tabel }}(9,17>1,67)$.

Hasil dari perhitungan jumlah skor variabel $\mathrm{X}$ dan skor variabel $\mathrm{Y}$, jika dimasukkan ke dalam rumus korelasi product moment untuk menghubungkan kedua variabel tersebut diperoleh nilai $r_{x y}$ sebesar 0,67 . Besarnya konstribusi variabel $\mathrm{X}$ terhadap variabel $\mathrm{Y}$ dapat dilihat dari besarnya nilai koefisien determinasi " $r$ " yaitu sebesar $44,89 \%$.

Untuk mengetahui signifikan tidaknya korelasi antara variabel $\mathrm{X}$ dengan variabel $\mathrm{Y}$, maka nilai koefisien korelasi yang didapat dari perhitungan dikonsultasikan dengan tabel " $\mathrm{r}$ " product moment. Pada taraf kepercayaan 0,05 dan $\mathrm{N}=105$ diperoleh harga $r_{\text {tabel }}$ sebesar 0,195. Berdasarkan hasil analisis data diperoleh nilai $\mathrm{r}_{\text {hitung }}$ lebih besar daripada rtabel (0,67> 0,195). Hal ini berarti $\mathrm{H}_{0}$ ditolak dan $\mathrm{H}_{1}$ diterima,sehingga dapat disimpulkan bahwa terdapat hubungan yang erat dan signifikan antara Profesionalisme Guru Pendidikan Agama Islam dengan mutu sekolah.

Hal ini menunjukkan adanya korelasi yang positif antara Profesionalisme Guru Pendidikan Agama Islam dengan mutu sekolah, sehingga dapat diinterpretasikan bahwa semakin tinggi nilai skor Profesionalisme Guru Pendidikan Agama Islam akan diikuti dengan tingginya skor mutu sekolah. Dengan kata lain, semakin tinggi tingkat Profesionalisme Guru Pen- didikan Agama Islam, maka akan semakin tinggi pula mutu sekolah. Sedangkan kontribusi Profesionalisme Guru Pendidikan Agama Islam terhadap mutu sekolah sebesar $44,89 \%$.

\section{Pembahasan}

Dalam pembahasan hasil penelitian dilakukan dari dua sisi, yaitu analisis deskripsi tiap variabel dan hasil analisis korelasi antar variabel. Berdasarkan hasil penelitian kualitatif dari keempat sumber dapat disimpulkan bahwa: a) Mutu sekolah di SMK Bhakti Anindya belum mencapai target $70 \%$, b) Menurunnya mutu sekolah disebabkan oleh rendahnya Profesionalisme Guru Pendidikan Agama Islam, c) Rendahnya Profesionalisme Guru Pendidikan Agama Islam karena alat pembelajaran yang sudah lama/rusak dan rendahnya insentif guru, d). Besarnya insentif guru menurun dikarenakan menurunnya input siswa baru dan keuangan sekolahnya berkurang, serta e) Menurunnya input siswa karena mutu sekolah yang kurang baik.

Tingkat Profesionalisme Guru Pendidikan Agama Islam diperoleh rentang 48 - 79 dengan rata-rata sebesar 62,419 menunjukkan skor rata-rata tergolong sedang dilihat dari ketercapaiannya pada skor rata-rata ideal yaitu ketercapaiannya $78 \%$ termasuk dalam kategori tinggi.

Profesionalisme Guru Pendidikan Agama Islam yang kuat memang sesuai dengan pendapat Abdul Rachman Shaleh ${ }^{18}$ bahwa kompetensi untuk Guru Pendidikan Agama Islam memerlukan persyaratan khusus yaitu: (1) Menuntut adanya keterampilan

${ }^{18}$ Abdul Rachman Shaleh, "Pendidikan Agama \& Pembangunan Watak Bangsa”, (Jakarta: PT Raja Grafindo Persada, 2006), hal 285 
yang mendalam mengenai teori pendidikan, keguruan, dan ilmu agama, (2) Menekankan pada keahlian sesuai dengan bidang profesinya, menguasai ilmu Agama Islam, terutama Al-Qur'an (termasuk kemampuan membaca fasih dan menulis yang benar), (3) Menuntut adanya tingkat pendidikan keguruan yang memadai, (4) Adanya kepekaan terhadap dampak kemasyarakatan dari pekerjaan yang dilaksanakannya, (5) Memungkinkan perkembangan sejalan dengan dinamika kehidupan (toleran, demokratif, inklusif, etos belajar, etos kerja, jujur dan seterusnya), dan (6) Memiliki komitmen, niat mengemban amanah, misi dakwah, atau mewakafkan diri sebagai Guru Pendidikan Agama Islam.

Hasil penelitian menunjukkan bahwa terdapat kontribusi positif Profesionalisme Guru Pendidikan Agama Islam terhadap mutu sekolah. Hal ini ditunjukkan dengan koefisien determinasi sebesar $44,89 \%$ yang memberikan informasi bahwa secara sederhana $44,89 \%$ variasi yang terjadi mutu sekolah ditentukan oleh Profesionalisme Guru pendidikan Agama Islam.

Pola hubungan antara kedua variabel tersebut, dinyatakan dengan persamaan regresi linier $\hat{Y}=12,268+0,83 X$. Persamaan ini memberikan informasi bahwa rata-rata perubahan satu skor Profesionalisme Guru Pendidikan Agama Islam diikuti oleh perubahan satu unit skor mutu sekolah sebesar 0,83. Dengan demikian dapat disimpulkan bahwa makin tinggi Profesionalisme Guru Pendidikan Agama Islam, maka makin tinggi pula mutu sekolah; dan sebaliknya makin rendah Profesionalisme Guru Pendidikan Agama Islam, maka makin rendah pula mutu sekolah.

Hasil penelitian menunjukkan bahwa $78 \%$ dari total responden menyatakan puas dengan mutu sekolah di SMK Bhakti Anin- dya, SMKN 8 dan SMK Tiara Aksara. Hal ini dapat disimpulkan bahwa Profesionalisme Guru Pendidikan Agama Islam membawa manfaat pada mutu sekolah yang ditunjukkan dari derajat kepuasan atas output peserta didik SMK Bhakti Anindya yang masih bersikap sopan dan masih mau mencium tangan guru-guru di sekolah, sekalipun sudah bekerja atau kuliah. Peserta didik masih melaksanakan sholat dhuha sekalipun tanpa penilaian dari Guru Pendidikan Agama Islam.

\section{KESIMPULAN}

Peran Guru Pendidikan Agama Islam dalam meningkatkan mutu sekolah di SMK Bhakti Anindya, SMKN 8 dan SMK Tiara Aksara Kota Tangerang yaitu: a) Guru sebagai sentral figur bagi peserta didik, b) Guru sebagai motivator bagi peserta didik, c) Guru sebagai seseorang yang memahami tingkat perkembangan intelektual peserta didik, dan d) Guru sebagai teladan bagi peserta didik.

Tingkat Profesionalisme Guru Pendidikan Agama Islam mencapai 78,00\% (dalam kategori baik) dengan indikator: memiliki komitmen yang baik kepada sekolah, dapat dijadikan tauladan dan figur yang baik bagi siswa dan rekan guru lainnya, memiliki pengetahuan yang handal sesuai bidangnya, rajin membuat administrasi guru, memiliki metode pengajaran yang selalu disesuaikan dengan kondisi peserta didiknya dan melaksanakan kewajiban beragama menurut Syariat Islam.

Terdapat pengaruh Profesionalisme Guru Pendidikan Agama Islam terhadap mutu sekolah (sebesar 44,89\%). Semakin tinggi tingkat Profesionalisme Guru Pendidikan Agama Islam, semakin tinggi pula mutu sekolah. Peningkatan Profesionalisme Guru Pendidikan Agama Islam akan diikuti dengan peningkatan mutu sekolah. 


\section{DAFTAR PUSTAKA}

Arif, Arifudin. Pengantar Ilmu Pendidikan, Jakarta: Kultura GP Press, 2008.

Bakar, Yunus Abu \& Nurjan, Syarifan. Profesi Keguruan, Surabaya: AprintA, 2009.

Hadis, Abdul \& Nurhayati, Manajemen Mutu Pendidikan, ( Bandung : Alfabeta, 2012)

Husaini, Usman. Manajemen: Teori, Praktik \& Riset Pendidikan.Jakarta: Bumi Aksara, 2014.

Ibnu, Abidin. Pemikiran Al-Ghazli tentang Pendidikan, Yogyakarta: Pustaka Pelajar, 1998.

Jaya, Irfan. "Permasalahan Pendidikan di Indonesia", http:/vancebatosai. blogspot.com, diakses 24 Oktober 2011.

Jakwan, Wawan."Pendidikan dan Pengajaran", http://www.fisika79.wordpress.com, diakses 16 Januari 2014.

Nurdin, Muhammad. Kiat Menjadi Guru Profesional, Yogyakarta: Prismasophie, 2004.

Shale, Rachman, Abdul.Pendidikan Agama \& Pembangunan Watak Bangsa, Jakarta: PT Raja Grafindo Persada, 2006.

Republik Indonesia, Undang-Undang Nomor 20 Tahun 2003 tentang Sistem Pendidikan Nasional, (Jakarta: BP Panca Usaha, 2003)

Sugiono, Metode Penelitian Kombinasi (Mixed Methods), Bandung: Alfabeta, 2014.

Syah, Darwyan \& Supardi.Pengantar Statistik Pendidikan, Jakarta: Diadit Media, 2009.

Umiarso \& Gojali, Imam.Manajemen Mutu Sekolah di Era Otonomi Pendidikan, Yogyakarta: IRCiSoD, 2011.

http://www.scribd.com/doc/183861226/Pera-
turan-Pemerintah-Nomor-19-Tahun - 2005 - tent ang - S t an dar-Nasional-Pendidikan-Lengkap diakses 13 November 2013. 